\title{
The Effect of Bullying Victim Psychoeducation Intervention on Decreasing Anxiety of High School Teenagers in Gorontalo Regency
}

\author{
Firmawati $^{1}$, Andi Nur Aina Sudirman ${ }^{1}$ \\ ${ }^{1}$ Nursing Science, Muhammadiyah University of Gorontalo
}

\begin{abstract}
In general, bullying is a school tradition carried out by seniors if they don't follow their rules, although there is also a lot of peer bullying. Victims of bullying are usually reluctant to complain to other parties, including parents because they are worried that they will get worse treatment. This study aims to determine the effect of bullying victim psychoeducation intervention on reducing the anxiety of high school adolescents in the Gorontalo Regency. This research method is a qualitative study with a pre-test and post-test design without a control group. The population in this study were high school adolescents. The sample in this study were 16 respondents. Data obtained through observation, questionnaires, interviews, and primary data obtained through data obtained from families and sufferers and related research. The results showed that there was a decrease in students' anxiety levels before and after the intervention. When viewed from the mean and standard deviation as well as the score in assessing the level of anxiety after being given psychoeducation to students who experience bullying at school, there is a decrease in the signs and symptoms of adolescent anxiety towards a better direction. Psychoeducation therapy in this research is in the form of cognitive strengthening, discussion, repeated counseling, anxiety management. In this study, interventions were given to respondents through bullying-related psychoeducation so that the anxiety level of adolescents decreased.
\end{abstract}

Keywords: Psychoeducation, Decreased Enxiety, Bullying Victims

Received : August 17, 2020

Received in Revised: August 25, 2020

Accepted: August 28, 2020

\section{Introduction}

The phenomenon of bullying includes bullying, bullying, hazing, bullying, exclusion, or intimidation. Bullying is aggressive behavior that is intentional and involves an imbalance of power or power. Anxiety or anxiety is a state of worrying that something bad is about to happen. There are many things that might be a source of anxiety for a person, for example, social relations, education, work, or health (Asrori, 2016).

Victims of bullying are usually students, and at the secondary level, victims of this violence are the parents and families of the victims. Bullying affects people who witness bullying such as peers in class or other students at school who know about bullying (Yoon \& Kerber, 2003; Bradshaw et al., 2007). This can lead to anxiety and feelings of insecurity or may lead to feelings of embarrassment due to a lack of effort to stop bullying (Smokowski \& Kopasz, 2005; Beane, 2008). However, if the school's response to bullying is weak, this will send a message to the bullying that they can bully without being punished or accept the consequences (Pečjak \& Pirc, 2017).

In general, bullying is a school tradition carried out by seniors if they don't follow their rules, although there is also a lot of peer bullying. Victims of bullying are usually reluctant to complain to other parties, including their parents because they are worried that they will get even worse treatment. This is what makes bullying even more rampant if it is not handled properly. Bullying can be defined as the act of hurting others verbally, physically, or 
psychologically to show power, causing trauma and feelings of pressure from the victim. Not only affects in the short term, but bullying can also affect a person in the long term, such as in terms of learning outcomes, physical and mental health, psychological well-being, feelings of inferiority, helplessness to cases of suicide.

Anxiety in adolescents is defined as a feeling of anxiety associated with an anticipation of the dangers that often occur during the development process. Anxiety in certain situations can be normal, such as feeling nervous or afraid when faced with something new or challenging. However, children with chronic anxiety disorder generally experience these feelings more intensely, for longer periods of time, and even in everyday situations.

Each level of anxiety has different characteristics or manifestations from one another. Mild anxiety, moderate anxiety, severe anxiety, and panic anxiety. (Asmadi, 2018). The long-term target of this research is how youth can be mentally healthy so that they can be independent and productive. Previously, it was necessary for the author to say that this research was in line with the implementation of the Healthy Indonesia program with a family approach (PISPK). This research is a research that has been designed to see how family empowerment by providing educational psychological therapy to reduce the anxiety of adolescents who experience bullying behavior in high schools / vocational high schools in Gorontalo Regency. Therefore, the purpose of this study is to determine the effect of bullying victim psychoeducation intervention on the reduction of high school adolescent anxiety in the Gorontalo Regency.

\section{Methods}

This research design used a pre-experimental with a quantitative approach pre-test and posttest without a control group. This research was conducted in SMA (High School)/SMK (Vocational School) Gorontalo Regency. The population used is students who experience bullying in SMA/SMK in the 2019/2020 school year. The sample in this study were 16 respondents. Types of data based on the source used in this study are two types of data, namely primary data obtained through observation, questionnaires, interviews, and primary data obtained through data obtained from families and patients and related research.

The instrument data collection tool consists of an observation sheet to measure respondents' anxiety, a family support questionnaire, a peer support questionnaire, and self-concept. The observation sheet to measure anxiety uses the HARS (Hamilton Anxiety Rating Scale) scale. The quantitative data analysis of data using a computer program to obtain an overview of the condition of every single variable, which is done by crosstabulation with experimental analysis with Quasi Experiments.

\section{Results and Discussion}

\section{Respondent Characteristics}

Table 1.Respondent characteristics based on age, gender, family support, peer support, and self-concept $(\mathrm{n}=16)$

\begin{tabular}{|c|c|c|}
\hline \multicolumn{1}{|c|}{ Variable } & Frequency & Percentage (\%) \\
\hline Age & 3 & 18,8 \\
15 Years & 5 & 31,2 \\
16 Years & 7 & 43,8 \\
17 Years & 1 & 6,2 \\
18 Years & \\
\hline
\end{tabular}




\begin{tabular}{|l|c|c|}
\hline \multicolumn{1}{|c|}{ Sex } & 4 & \\
Male & 12 & 25 \\
Female & 8 & 75 \\
\hline \multicolumn{1}{|c|}{ Family Support } & 50 \\
Good & 3 & 18,8 \\
Enough & 5 & 31,2 \\
Less Peer Support & 8 & \\
\hline \multicolumn{1}{|c|}{ Pood } & 4 & 50 \\
Enough & 4 & 25 \\
Less Self Concept & 7 & 25 \\
\hline Good & 7 & 43,8 \\
Enough & 2 & 43,8 \\
Less & & 12,5 \\
\hline
\end{tabular}

Source: Processed Primary Data 2020

Based on table 1. The distribution of the characteristics of respondents based on the age of most respondents was 17 years $(43.8 \%)$ and the lowest was 18 years $(6.2 \%)$. Characteristics based on Gender The majority of women, namely 12 people (75\%). Characteristics based on the highest family support were good family support as many as 8 people (50\%) and the lowest was adequate family support as many as 3 people $(18.8 \%)$. Characteristics based on the highest peer support is good peer support as many as 8 people (50\%). Characteristics based on the highest self-concept are those who have a good self-concept as many as 7 people $(43.8 \%)$ and the lowest who have a lack of self-concept, namely 2 people $(12.5 \%)$.

\section{Univariate Analysis}

Table 2. The average level of student anxiety before and after giving the intervention in 2020

\begin{tabular}{|c|c|c|c|c|}
\hline Measurement & Mean & $\mathbf{N}$ & $\begin{array}{c}\text { Standard } \\
\text { Deviation }\end{array}$ & Minimal-Maximal \\
\hline Before & 2,69 & 16 & 0,479 & $2-3$ \\
\hline After & 1,69 & 16 & 0,704 & $1-3$ \\
\hline
\end{tabular}

Source: Processed Primary Data 2020

In the univariate table 2 above, the average level of student anxiety before the intervention was with a mean value of 2.69 and SD 0.479 while after intervention decreased with a mean value of 1.69 and SD 0.704 .

\section{Bivariate Analysis}

Table 3. Differences in the average level of student anxiety before and after giving the intervention in 2020

\begin{tabular}{|c|c|c|c|c|}
\hline $\begin{array}{c}\text { Anxiety } \\
\text { Level }\end{array}$ & Mean & $\begin{array}{c}\text { Standard } \\
\text { Deviation }\end{array}$ & P-Value & N \\
\cline { 1 - 3 } Before & 2,69 & 0,479 & 0,001 & 16 \\
\hline After & 1,69 & 0,704 & 0,016 \\
\hline
\end{tabular}

Source: Processed Primary Data 2020 
In the Bivariate 3 table above, it is known that the results of statistical tests before and after giving intervention to assess the average difference in anxiety levels of 16 students showed a $\mathrm{p}$-value $=0.001$.

\section{Multivariate Logistic Regression Analysis}

Table 4. Full Model Multivariate Analysis Factors that affect the level of anxiety in students suffering from bullying in $2020(\mathrm{n}=16)$

\begin{tabular}{lccc}
\hline \multicolumn{1}{c}{ Variable } & B & P-value & $\mathbf{9 5 \%}$ Cl \\
\hline $\begin{array}{l}\text { Family } \\
\text { Support }\end{array}$ & 0,350 & 0,545 & $0,029-10,482$ \\
\hline $\begin{array}{l}\text { Peer } \\
\text { Support }\end{array}$ & 1,843 & 0,671 & $0,110-31,009$ \\
\hline $\begin{array}{l}\text { Self } \\
\text { Concept }\end{array}$ & 12,368 & 0,126 & $0,494-309,373$ \\
\hline
\end{tabular}

Source: Processed Primary Data 2020

After doing the analysis, it was found that the dominant factor seen from the variable that has the highest B coefficient is self-concept so that the variables of family support and peer support act as controlling variables.

The results of the research on the characteristics of respondents based on the age of most respondents were 17 years and the lowest was 18 years. At 18 years of age, the level of anxiety is lower than that of 17 years. The results of the research on the characteristics of respondents based on gender, victims of bullying who experienced anxiety were the majority of women. In determining one's self-defense against anxiety, it is influenced by gender.

The results showed that there was a decrease in students' anxiety levels before and after the intervention. When viewed from the mean and standard deviation as well as the score in assessing the level of anxiety after being given psychoeducation to students who experience bullying at school, there is a decrease in the signs and symptoms of adolescent anxiety towards a better direction.

Psychoeducation therapy in this research is in the form of cognitive strengthening, discussion, repeated counseling, anxiety management. In this study, interventions were given to respondents through bullying-related psychoeducation so that the anxiety level of adolescents decreased. Before doing psychoeducation therapy, the respondents' level of anxiety had been measured first. This activity is carried out in two stages, the first stage is providing education to respondents regarding the definition of bullying, types of bullying, signs, and symptoms, and how the process is handled. The next stage is anxiety management education. In addition, respondents were also invited to explore their feelings of anxiety and invite respondents to exchange ideas and share experiences related to what they experienced. Psychoeducation intervention is carried out by lecturing, discussion, and demonstration methods in small groups or individuals and then giving leaf templates as reading material when the respondent is at home after being given the intervention.

Positive self-concepts tend to have a low level of bullying because they are able to accept themselves and others well, are able to recognize themselves, have clear goals in life, and continue to evaluate from within and think positively can reduce bullying behavior ( Houbre 
et al., 2006; Roeleveld, 2011). The term Bullying has not been widely known by the public, especially because there is no proper equivalent in Indonesian. Several terms in Indonesian are often used to describe (Masdin, 2013).

Efforts are needed to control negative thoughts that arise due to bullying behavior which results in anxiety or other bad thoughts that occur because of being a victim of bullying. Thoughts that cause anxiety can disturb someone so that they become less and even unproductive. For example, some respondents admitted that they were reluctant to go to school because they were worried about meeting the bullying. This will result in psychological discomfort.

Family therapy is especially useful when the disruption of family interactions interferes with teen development. A series of family therapy sessions may be sufficient, and adolescents benefit from individual or group approaches to support efforts to separate emotional feelings from the family (Powell \& Ladd, 2010). some family therapy sessions do not require direct nursing action. Regardless of the therapeutic modality chosen when providing nursing care to adolescents, family orientation and adolescent's efforts to separate from family and become independent adults should be considered.

Group therapy addresses adolescents' need for peer support. The conflict between dependence and independence with adults is lessened by the presence of other adolescents. Group therapy assists adolescents' need for positive, helpful peer groups in shaping identity. Conducting individual therapy, an agreement or contract between the nurse and the adolescent begins to establish and a therapeutic relationship. Nurse therapeutic ties are oriented towards the reality of adolescent conditions and their health. Cognitive strengthening, structured counseling, and stress management. This therapy can eliminate negative thoughts and bad perceptions that the youth victims of bullying have.

\section{Conclusion}

This intervention can be one of the considerations for use by teachers, especially in counseling in every school to deal with bullying in adolescents. Psychoeducation interventions are effective in reducing anxiety levels in adolescents who experience bullying. This therapy consists of cognitive strengthening, structured counseling, and stress management. This therapy can eliminate negative thoughts and bad perceptions that the client has. The client's anxiety will reduce concentration, think, and narrow the area of thought. This therapy shows a reduction in anxiety levels by training the client to resist thoughts and control disturbing thoughts. The decrease in anxiety levels in adolescents is also influenced by a good self-concept. It is necessary to have the support and always think positively and instill a positive self-concept in students which are very important in reducing bullying behavior.

\section{References}

Asmadi, A. (2018). Teknik prosedural keperawatan: konsep dan aplikasi kebutuhan dasar klien (19). Salemba Medika.

Asrori, A. (2016). Terapi kognitif perilaku untuk mengatasi gangguan kecemasan sosial. Jurnal Ilmiah Psikologi Terapan, 3(1), 89-107.

Masdin, M. (2013). Fenomena bullying dalam pendidikan. Al-Ta'dib, 6(2), 73-83.

Roeleveld, W. (2011). The relationship between bullying and the self-concept of children. Social Cosmos, 2, 111-116. 
Houbre, B., Tarquinio, C., Thuillier, I., \& Hergott, E. (2006). Bullying among students and its consequences on health. European Journal of Psychology of Education, 21(2), 183208.

Smokowski, P. R., \& Kopasz, K. H. (2005). Bullying in school: An overview of types, effects, family characteristics, and intervention strategies. Children \& Schools, 27(2), 101-110.

Powell, M. D., \& Ladd, L. D. (2010). Bullying: A review of the literature and implications for family therapists. The American Journal of Family Therapy, 38(3), 189-206.

Beane, A. L. (2008). Protect your child from bullying: Expert advice to help you recognize, prevent, and stop bullying before your child gets hurt. John Wiley \& Sons.

Bradshaw, C. P., Sawyer, A. L., \& O’Brennan, L. M. (2007). Bullying and peer victimization at school: Perceptual differences between students and school staff. School psychology review, 36(3), 361-382.

Yoon, J. S., \& Kerber, K. (2003). Bullying: Elementary teachers' attitudes and intervention strategies. Research in Education, 69(1), 27-35. 